\title{
The modulation of myocellular fat stores; lipid droplet dynamics in health and disease
}

Citation for published version (APA):

Meex, R. C., Schrauwen, P., \& Hesselink, M. K. (2009). The modulation of myocellular fat stores; lipid droplet dynamics in health and disease. American Journal of Physiology-regulatory Integrative and Comparative Physiology, 297(4), R913-924. https://doi.org/10.1152/ajpregu.91053.2008

Document status and date:

Published: 01/01/2009

DOI:

10.1152/ajpregu.91053.2008

Document Version:

Publisher's PDF, also known as Version of record

Document license:

Taverne

Please check the document version of this publication:

- A submitted manuscript is the version of the article upon submission and before peer-review. There can be important differences between the submitted version and the official published version of record.

People interested in the research are advised to contact the author for the final version of the publication, or visit the DOI to the publisher's website.

- The final author version and the galley proof are versions of the publication after peer review.

- The final published version features the final layout of the paper including the volume, issue and page numbers.

Link to publication

\footnotetext{
General rights rights.

- You may freely distribute the URL identifying the publication in the public portal. please follow below link for the End User Agreement:

www.umlib.nl/taverne-license

Take down policy

If you believe that this document breaches copyright please contact us at:

repository@maastrichtuniversity.nl

providing details and we will investigate your claim.
}

Copyright and moral rights for the publications made accessible in the public portal are retained by the authors and/or other copyright owners and it is a condition of accessing publications that users recognise and abide by the legal requirements associated with these

- Users may download and print one copy of any publication from the public portal for the purpose of private study or research.

- You may not further distribute the material or use it for any profit-making activity or commercial gain

If the publication is distributed under the terms of Article $25 \mathrm{fa}$ of the Dutch Copyright Act, indicated by the "Taverne" license above, 


\title{
Modulation of myocellular fat stores: lipid droplet dynamics in health
}

\section{and disease}

\author{
Ruth C. R. Meex, ${ }^{\mathbf{1}}$ Patrick Schrauwen, ${ }^{2}$ and Matthijs K. C. Hesselink ${ }^{1}$ \\ NUTRIM School for Nutrition, Toxicology and Metabolism, Departments of ${ }^{1}$ Human Movement Sciences and ${ }^{2}$ Human \\ Biology, Maastricht University Medical Center, Maastricht, the Netherlands
}

Submitted 29 December 2008; accepted in final form 14 August 2009

\begin{abstract}
Meex RC, Schrauwen P, Hesselink MK. Modulation of myocellular fat stores: lipid droplet dynamics in health and disease. Am J Physiol Regul Integr Comp Physiol 297: R913-R924, 2009. First published August 19, 2009; doi:10.1152/ajpregu.91053.2008.- Storage of fatty acids as triacylglycerol (TAG) occurs in almost all mammalian tissues. Whereas adipose tissue is by far the largest storage site of fatty acids as TAG, subcellular TAG-containing structures-referred to as lipid droplets (LD) - are also present in other tissues. Until recently, LD were considered inert storage sites of energy dense fats. Nowadays, however, LD are increasingly considered dynamic functional organelles involved in many intracellular processes like lipid metabolism, vesicle trafficking, and cell signaling. Next to TAG, LD also contain other neutral lipids such as diacylglycerol. Furthermore, LD are coated by a monolayer of phospholipids decorated with a variety of proteins regulating the delicate balance between LD synthesis, growth, and degradation. Disturbances in LD-coating proteins may result in disequilibrium of TAG synthesis and degradation, giving rise to insulin-desensitizing lipid intermediates, especially in insulin-responsive tissues like skeletal muscle. For a proper and detailed understanding, more information on processes and players involved in LD synthesis and degradation is necessary. This, however, is hampered by the fact that research on LD dynamics in (human) muscle is still in its infancy. A rapidly expanding body of knowledge on LD dynamics originates from studies in other tissues and other species. Here, we aim to review the involvement of LD-coating proteins in LD formation and degradation (LD dynamics) and to extrapolate this knowledge to human skeletal muscle and to explore the role of LD dynamics in myocellular insulin sensitivity.
\end{abstract}

adipose triglyceride lipase; hormone-sensitive lipase; perilipin adipocyte differentiation-related proteins; muscle

STORAGE OF FAT IN WHITE ADIPOSE tissue (WAT) is the most widely studied form of triacylglycerol (TAG) storage. In periods of caloric excess, adipose tissue mass expands by increasing TAG content. During starvation, hydrolysis of TAG results in mobilization of fatty acids to meet the organism's energy requirement and TAG content in adipocytes declines. Stored TAG, hence, represents a dynamic pool of fatty acids.

Whereas adipose tissue is by far the largest storage site of fatty acids as TAG, almost all mammalian cell types have the ability to store fatty acids as TAG in lipid droplets (LD), so-called ectopic fat storage. The LD-coating phospholipid monolayer is covered with phospholipids, cholesterol, and proteins. Next to TAG, LD also contain other neutral lipids like diacylglycerols (DAG), cholesteryl esters, retinyl esters, and free cholesterol. Lipid droplets may range in size from $200 \mu \mathrm{m}$ in diameter to microlipid bodies of only $50 \mathrm{~nm}$ in diameter, depending on the cellular lipid load and cell type (92).

Nowadays, LD are considered dynamic functional organelles. Next to lipid metabolism, LD are also involved in

Address for reprint requests and other correspondence: M. Hesselink, Dept. of Human Movement Sciences, NUTRIM School for Nutrition, Toxicology and Metabolism, Maastricht Univ. Medical Center, PO Box 616, NL-6200 MD, Maastricht, The Netherlands (e-mail: matthijs.hesselink@bw.unimaas.nl). vesicle trafficking and cell signaling $(16,92)$. The physiological role of lipid droplets varies with the subcellular localization, the morphology, and the (sub)proteome of the droplet. In adipocytes, the cytoplasm is almost entirely occupied by the LD, whereas in tissues with a high lipolytic rate like cardiac and skeletal muscle, numerous small LD are present. Size, and possibly function, is sensitive to diet, disease, nutritional status, and training status (92) and on the balance between LD synthesis and LD degradation.

Abundant storage of TAG in LD in metabolically dynamic tissues like cardiac and skeletal muscle, as well as the liver and pancreas, may interfere with subcellular processes like insulin signaling. Thus, a strong positive correlation between ectopic TAG storage, measured by ${ }^{1} \mathrm{H}$ NMR spectroscopy as intramyocellular lipid content (IMCL), and insulin resistance $(57,69,101)$ has been reported in insulinresistant subjects. Interestingly, endurance training, an insulin-sensitizing intervention, also coincides with increased IMCL content (40). In fact, we have shown that an increase in IMCL is a very early response to training (119). In addition, it has been shown that a 4-mo-insulin sensitizing intervention of combined weight loss and physical activity significantly decreased LD size, without a decline in total myocellular triacylglycerol content (49). It is, therefore, 
unlikely that the presence of LD per se impedes insulin signaling. Rather, it has been hypothesized that intermediates in LD synthesis and degradation, such as DAG, ceramides, and fatty acyl CoA esters might be responsible (56, $104,112,122)$. The balance between LD synthesis and degradation, here referred to as LD dynamics, partly determines the fraction of lipid-derived intermediates.

In adipocytes, the phospholipid monolayer coating the LD is decorated with several proteins involved in lipid droplet dynamics referred to as PAT proteins. PAT proteins [perilipin, ADRP (for adipocyte differentiation-related protein), and TIP47 (for tail-interacting protein of $47 \mathrm{kDa}$ )]. are characterized by a common N-terminal motif (PAT domain). Other recently discovered proteins, like S3-12 and OXPAT, possess a high-sequence homology with the PAT domain and are also considered PAT proteins. Throughout this review, we will use the term PAT proteins not only for perilipin, ADRP, and TIP-47, but also for S3-12 and OXPAT.

To better understand the origin of insulin-desensitizing lipid moieties in skeletal muscle, a detailed understanding of the processes involved in LD formation and degradation is hence warranted. To date, however, data on LD dynamics in (human) muscle are still scarce. A rapidly expanding body of knowledge on LD dynamics comes from studies in other tissues and other species. Therefore, we aim to review the current prevailing knowledge on the process of LD synthesis and degradation and to extrapolate this knowledge to human skeletal muscle and, where data allow, explore the putative involvement in muscular insulin sensitivity.

\section{Lipid Droplet Hydrolysis}

Hydrolysis of TAG stored in LD, requires a tight interplay between multiple lipases. Tight (co)regulation of two major lipases hormone-sensitive lipase (HSL) and adipose triglyceride lipase (ATGL) has been demonstrated in human adipose tissue $(61,73,81)$. It can be hypothesized that an imbalance between HSL and ATGL activity affects the level of insulindesensitizing intermediates like DAG, not only in adipose tissue but also in peripheral tissues like skeletal muscle.

HSL. Hormone sensitive lipase (HSL) is a cytosolic protein with three isoforms of which one (the $84-\mathrm{kDa}$ isoform) is abundantly present in adipose tissue (141) and in lesser amounts in cardiac and skeletal muscle (51, 67, 72, 123). Phosphorylation of specific serine residues of HSL results in activation of HSL and subsequent translocation from the cytosol to the phospholipid monolayer covering the LD to exert lipolytic activity $(14,23,33)$. HSL has affinity to multiple lipid-related substrates (reviewed in Ref. 52). Here, we will focus on its affinity to TAG, DAG, and monoacylglycerol (MAG).

Activation of HSL can occur via a hormonal route and-in case of muscle- a contraction-mediated route. In the hormonal route, binding of catecholamines increases cAMP levels, thereby activating PKA. Subsequently, phosphorylation of HSL activation sites (Ser-563, Ser-659, and Ser-660) occurs (2, $5,72,146)$. Adrenergic activation of HSL can be blunted by insulin via activation of $\mathrm{AKT} / \mathrm{PKB}$ and $\mathrm{PDE} 3 \mathrm{~B}$, resulting in degradation of cAMP, thereby interfering with adrenergic activation of lipolysis $(28,78,94,149)$. Although hormonal regulation of lipolysis in muscle is similar to adipose tissue lipolysis, the contractile nature of muscle and the resultant rapid fluctuations in energy requirement need additional routes to control muscle lipolysis. Physical exercise enhances circulatory adrenalin levels and increases muscle AMPK activity. Stimulation of muscle lipolysis by exercise-induced increases in adrenalin can partly be blunted by AMPK-dependent phosphorylation of HSL at inactivating serine residues Ser-565 in skeletal muscle (possibly to adjust lipolytic rate to exercise intensity), this AMP-dependent inactivation is not reported in adipose tissue (145-147). Increases in $\mathrm{Ca}^{2+}$ in the sarcolemma, which initiates muscle contraction, also results in activation of PKC and its downstream target ERK and subsequent HSL activation $(30,45)$. These effects jointly regulate fine-tuning of exercise-induced activation of muscle lipolysis to fuel muscle contraction during graded exercise, as well as during prolonged exercise.

$A T G L$. For the past 30 years, HSL was considered the only lipase involved in TAG degradation. Interestingly, in HSL knockout mice, total adipose tissue mass did not change (100, 143), while hydrolysis of TAG was still possible, but DAG levels were increased (48). This suggests that a lipase other than HSL must be involved in TAG hydrolysis. This protein has been identified and was named adipose triglyceride lipase (ATGL) (162). Independent studies identified the same protein at about the same time and called it iPLA2 (58) and desnutrin (142). ATGL is well preserved across species, and homologues have been reported in yeast [Tgl4 (7)], in plants [SUGARDEPENDENT1 lipase (31)], and in Drosophila [Brummer lipase (46)]. Here, we will use the term ATGL for this lipase.

ATGL mRNA is predominantly expressed in WAT and brown adipose tissue (BAT), and to a lesser extent in cardiac and skeletal muscle $(47,60,63,65,142,162)$. Cell studies revealed PPAR $\gamma$-mediated control of ATGL gene expression $(65,142)$. Both thiazolidinedione-based PPAR $\gamma$ agonists and nonthiazolidinedione-based PPAR $\gamma$ agonists increased ATGL mRNA and ATGL protein in 3T3-L1 adipocytes (64). Knockdown of PPAR $\gamma$ reduced ATGL mRNA and protein expression in adipocytes (64). Treating mice with rosiglitazone increased ATGL mRNA and protein content $(64,77,121)$.

During fasting, a state in which PPAR $\gamma$ is activated through elevated free fatty-acid levels, ATGL mRNA and ATGL protein expression is upregulated $(63,142)$. Refeeding results in a decreased transcription of ATGL in mice $(63,65)$. Decreases in transcription of the ATGL gene after refeeding can be a direct effect of reduced PPAR $\gamma$ activity in adipose tissue; it can also be mediated via insulin, transient hyperglycemia or reduced FFA levels by insulin-mediated suppression of adipose tissue lipolysis. Later studies revealed that transcriptional control of the ATGL gene in adipose tissue is under control of insulin rather than glucose $(63,65,68)$. Thus, ATGL appears to be under control of PPAR $\gamma$, as well as insulin.

In 3T3-L1 adipocytes and under basal conditions, the majority of ATGL protein was present in the cytoplasm, whereas a distinct fraction of ATGL was tightly associated with LD (162). ATGL hydrolyzes the first ester bond of TAG and is likely to limit lipolysis in smooth muscle, cardiac muscle, and possibly skeletal muscle $(47,48,120)$. Although knock-down of ATGL (or its homologue Brummer lipase in the case of Drosophila) resulted in a decreased lipolysis and an increase in LD size in Drosophila, 3T3-L1 cells and in HeLa cells (35, 46, $63,124)$, adipose tissue mass in mice lacking ATGL was 
increased, but not massively. Rather, fat storage in nonadipose tissue increased to supraphysiological levels in skeletal and cardiac muscle $(47,120)$. At 12 wk of age, a striking 20-fold rise in cardiac TAG content was observed. As a result of the increase in TAG accumulation, cardiac function was severely hampered, and the knockout of ATGL resulted in cardiac failure and premature death (47). In humans, carriers of a ATGL polymorphism, resulting in lower ATGL activity, possess excessive ectopic TAG accumulation along with myopathy (35).

Reduced TAG lipolysis in muscle of ATGL knockout mice was paralleled by a decrease in fat oxidation and a concomitant increase in glucose oxidation during fasting and an unanticipated increased glucose uptake $(47,54)$. Increased glucose uptake by the muscle, despite excessive TAG storage, may reflect substrate availability; in the absence of ATGL activity, fatty acids cannot be released from the LD and can hence not be used as an energy source. Thus glucose uptake and oxidation must increase to meet the energy demand.

The relatively modest ( $\sim 2$ fold) increase in adipose tissue mass and liver fat in ATGL knockout mice (47), suggests that in these tissues ATGL may not be the major TAG lipase. In cardiac muscle and to a lesser extent in skeletal muscle, however, TAG storage in ATGL knockout mice is more pronounced, suggesting an important role for ATGL-based lipolysis of TAG in muscle. Overexpression of ATGL in 3T3-L1 cells, COS-7 cells, and HeLa cells (46, 63, 124, 142), as well as overexpression of the Brummer lipase (homologue of human ATGL) in Drosophila (46, 63, 124,142$)$, resulted in increased TAG lipolysis and a concomitant decrease in LD size. Unilateral overexpression of ATGL in skeletal muscle increased oxidation of LD-derived fatty acids and increased insulin-desensitizing lipid intermediates like DAG and ceramide (148), suggesting that increased ATGL activity was not matched with increased HSL activity. Thus, disequilibrium between ATGL and HSL activity may increase DAG content and impede insulin signaling.

In diet-induced obese C57BL/6J mice and $o b / o b$ mice low ATGL protein levels have been reported in muscle along with high muscle TAG storage $(65,142,148)$. In contrast to ATGL protein levels, however, ATGL mRNA expression was higher in skeletal muscle of C57BL/6J high-fat mice and $o b / o b$ mice compared with nonobese controls (148). Similar observations have been made in subcutaneous adipose tissue of obese subjects, in which low ATGL protein content was observed along with high levels of ATGL mRNA (127), suggesting that posttranscriptional processes profoundly affect ATGL protein content. Despite the dissociation between mRNA expression and protein content, the above-mentioned studies indicate an association between myocellular ATGL and obesity. In adipose tissue, however, diet-induced obesity in mice did not affect ATGL protein content $(64,121)$, and ATGL mRNA levels in $o b / o b$ mice were comparable to lean littermates (71). Similarly, in adipose tissue of obese humans, ATGL gene expression (81) or protein content (114) was comparable to nonobese subjects. Furthermore, in insulin-resistant subjects, adipose tissue ATGL mRNA levels were lower compared with obese subjects with preserved insulin sensitivity irrespective of body fat mass or fat distribution (9).

In insulin-resistant subjects, weight loss resulted in a decrease in ATGL and HSL mRNA- and protein level (61), but in insulin-nonresistant subjects, this decrease was not detected (81). However, the insulin-resistant subjects were studied in negative energy balance, whereas the insulin-nonresistant subjects were studied after energy balance was restored (81). In normoglycemic young men, exercise training resulted in increased ATGL protein in muscle without changes in HSL protein level, but with a decline in muscle TAG content (4). Strikingly, exercise training in general improves insulin sensitivity, whereas the changes observed here could imply increased DAG levels, which is supposed to impede insulin sensitivity. Unfortunately data on DAG or insulin sensitivity have not been reported in this study.

ATGL activity requires coactivation by comparative gene identification-58 (CGI-58), also known as $\alpha / \beta$-hydrolase domain containing 5 (ABHD5) $(74,120,160)$. CGI-58 stimulates TAG hydrolysis in wild-type and HSL-deficient adipose tissue but fails to activate lipolysis in the absence of ATGL, suggesting that CGI-58 is not a lipase as such, but rather facilitates lipolysis by ATGL but not HSL (120). ATGL activity was enhanced 20-fold in the presence of CGI-58 (74). Furthermore, a mutation in CGI-58 is associated with Chanarin-Dorfman Syndrome, a rare genetic disease resulting in excessive ectopic TAG accumulation. Reintroduction of functional CGI-58 normalizes the TAG content in peripheral tissues of these patients (74). These results indicate that CGI-58 is required to maximize the rate of TAG hydrolysis. Regulation of ATGL activity by CGI-58 requires interaction with lipid droplet-coating proteins of the PAT family, which will be discussed in Lipid droplet-binding proteins not related to the PAT family.

Several studies have provided evidence that ATGL and HSL act coordinately in hydrolyzing triglycerides (73). The current hypothesis states that ATGL hydrolyzes the first ester bond of the TAG molecule, whereas HSL preferentially degrades DAG $(36,120)$. Data indicate that this is the case for TAG stored in adipose tissue, as well as for TAG stored ectopically. A disequilibrium in ATGL and HSL activation in insulin-responsive tissues like muscle may increase the content of the insulin-desensitizing lipid intermediate DAG. So far, however, this putative disequilibrium has not been reported in muscle of type 2 diabetic subjects.

$M G L$ and other lipases. Information on the role and regulation of monoacylglycerol lipase (MGL) is limited, especially for ectopically stored fat. Given the specific affinity of ATGL for TAG and of HSL for DAG, another lipase with a high affinity for MAG hydrolysis could be of importance in adipose tissue and skeletal muscle. In adipose tissue, it has, indeed, been shown that MGL is of importance for complete hydrolysis of MAG (37). Experiments in murine white adipose tissue in vitro to examine the relative contribution of ATGL and HSL to total lipolysis revealed that joint action of ATGL and HSL is responsible for $95 \%$ of total hydrolytic activity (120), suggesting a quantitatively minor role for other lipases, including MGL.

Triacylglycerol hydrolase (TGH) and triacylglycerol hydrolase homologue (TGH-2) are TAG-specific lipolytic enzymes highly expressed in liver and adipose tissue (98). In contrast to ATGL and HSL, TGH and TGH-2 efficiently hydrolyze triacylglycerol comprising short-chain fatty acids. Because of hepatic conversion of short-chain fatty acids into long-chain fatty acids by elongases and the absence in muscle of a short-chain fatty-acid specific synthase, the vast majority of the TAG 
stored in the human body comprises long-chain fatty acids. Whereas the quantitative role of TGH and TGH-2 in hydrolysis of hepatic TAG may be highly relevant, its role in hydrolysis of myocellular TAG may be less prominent.

Jointly, ATGL and HSL can hydrolyze the vast majority of the TAG in adipose tissue and skeletal muscle; at present, there is little reason, suggesting that defects in hydrolysis of MAG in skeletal muscle can play a major role in modulating lipiddesensitizing intermediates in skeletal muscle.

\section{Lipid Droplet-Coating Proteins}

The LD is coated by a phospholipid monolayer decorated with a family of proteins, referred to as PAT proteins, characterized by a common $\mathrm{NH}_{2}$-terminal motif. PAT refers to perilipin, ADRP, and TIP47, but the PAT family also comprises S3-12 and OXPAT, two proteins with sequence homology and/or similar function as the originally identified PAT proteins. Each of these PAT proteins has a unique tissue distribution and lipid-binding properties. In addition, all PAT proteins identified so far can localize to LD, whereas TIP47 are also present in other subcellular compartments. Thus, it is likely that the different PAT proteins may have (at least partly) distinct roles in TAG management.

Perilipin. In adipose tissue, activation of perilipin by phosphorylation is required for full activation of HSL-related hydrolysis. Perilipin is the predominant PAT protein in adipose tissue involved in control of storage and degradation of lipid stored in the $\operatorname{LD}(1,39,125,126)$. Expression of perilipin is under control of the transcription factor PPAR $\gamma(1,6,26)$, and perilipin is predominantly found on the LD of adipose tissue $(10,43,103)$. In the fed state and in the presence of insulin, perilipin is not phosphorylated on PKA site serines and coats the LD in adipose tissue $(32,89)$, thereby limiting lipolytic activity of HSL to lipid stored in the LD $(15,88)$. In contrast, under lipolytic conditions, perilipin gets phosphorylated by PKA $(15,43,44)$, allowing HSL to access the $\operatorname{LD}(88,91,126$, $132,133)$. In line with this, TAG levels in adipose tissue of perilipin knockout mice $(83,133)$ and in cells lacking perilipin is reduced $(15,83,88)$, suggesting a pivotal role for perilipin in regulating HSL activity. Despite higher lean body mass and an increased metabolic rate, perilipin-null mice tend to develop glucose intolerance and peripheral insulin resistance (115). Interestingly, perilipin levels in adipose tissue from obese Zucker rats and obese humans appear lower than in lean controls if matched for fat cell mass $(26,91,144)$. It is important to note that most of the data on regulation of lipolyis of lipid stored in LD and of interaction of perilipin with HSL has been published in the pre-ATGL era, and hence, one cannot exclude the possibility that some of these observations have been confounded by lipase activity of ATGL, which by then, was not yet discovered.

Although hydrolysis of TAG in myocellular LD involves HSL activity, skeletal muscle is devoid of perilipin. Rather, adrenaline and contractile activity-associated increases in TAG hydrolysis in myocellular LD goes along with recruitment of HSL to ADRP and TIP-47-coated LD (105), suggesting that these PAT proteins may be myocellular analogs of perilipin that operate in muscle to control basal and stimulated lipolysis.

$A D R P$. Shortly after the discovery of perilipin, adipose differentiation-related protein (ADRP) was identified $(34,59)$.
ADRP is expressed in a wider range of tissues than perilipin $(13,50)$, including rodent and human skeletal muscle (103, 105). ADRP is involved in the uptake of long-chain fatty acids from the cytoplasm and incorporation of fatty acids in $\operatorname{LD}(20$, $38,76,80,85)$. In livers from $o b / o b$ mice (116) and etomoxir (i.e., CPT-1 inhibitor)-treated rats (128) and in specific diseases states involving ectopic fat accumulation $(50,90)$, ADRP expression is increased.

Like perilipin, ADRP decorates the LD membrane, thus affecting lipolytic activity of ATGL and recruitment of another PAT protein, TIP47, to the lipid droplet $(76,97)$. In ADRPexpressing tissues, hydrolysis of TAG in LD might indeed be under control of ADRP $(105,150)$. Tissue-specific and whole body knockout studies of ADRP resulted in resistance to diet-induced hepatic steatosis, while adipocyte differentiation and lipolysis were unaffected (20). The absence of changes in adipogenesis may originate from a compensatory induction of TIP47. In ADRP knockout cells with concomitant siRNAmediated downregulation of TIP47, LD formation was attenuated, and fatty acids added to the system incorporated into phospholipids in cellular membranes other than LD (131). Downregulation of hepatic ADRP using antisense oligonucleotides reduced hepatic steatosis, hypertriglyceridemia, and insulin resistance in obese mice (55) and rescued diet-induced obese mice from developing insulin resistance. These favorable effects were attributed to lower levels of the insulindesensitizing lipid intermediate DAG in the livers of the treated animals (140).

ADRP may also be involved in regulating subcellular localization of the LD. In preadipocytes, ADRP associates with the intermediate filament protein vimentin $(10,43,103)$, suggesting that intracellular trafficking of the lipid droplets may occur. This notion was substantiated by the observation that the microtubular motor protein dynein-allowing the droplet to move within the cell along the microtubular system-coprecipitated with ADRP (12). Extending these observations to skeletal muscle is intriguing; in mature skeletal muscle, LD can be found in a highly organized manner along myofibrils and adjacent to Z-discs (Fig. 1) in direct vicinity of the Z-disc interconnecting intermediate filament desmin (102). The highly organized subcellular structure of skeletal muscle is initiated during differentiation when vimentin expression decreases and desmin expression increases, allowing alignment of myofibrils in a regular array of Z-discs interconnected by desmin (139). In this respect, it is interesting to note that in fully differentiated skeletal muscle, the motor protein dynein and a microtubular network machinery both are present to traffic nascent $\mathrm{LD}$ from the ER toward a location in vicinity of the Z-disc and in association with mitochondria.

In 3T3-L1 preadipocytes and in early stages of differentiating 3T3-L1 adipocytes, the gene encoding for ADRP is induced, and ADRP protein content increases $(13,59)$. In fully differentiated adipocytes, however, ADRP protein levels drop, despite the persistence of high levels of ADRP mRNA. At the protein level, it has been shown that maintenance of ADRP content highly depends on the amount of neutral lipids present in the cell. ADRP, which is not bound to neutral lipids, is posttranslationally targeted for proteasomal degradation (84, 157).

Like perilipin, the ADRP promoter contains a PPAR-responsive element. Likewise, ADRP gene expression can be stimu- 

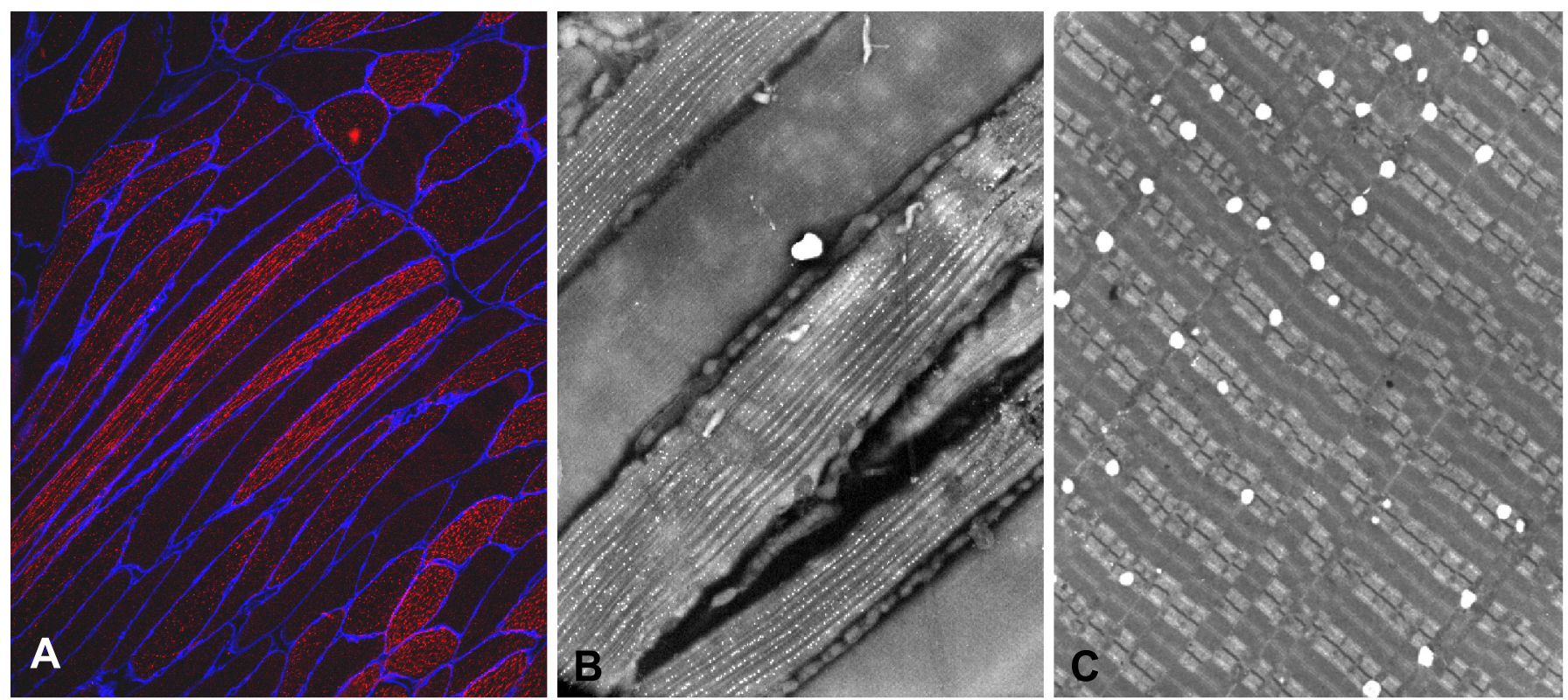

Fig. 1. Lipid droplets in skeletal muscle are deposited in a highly organized manner, revealing a string of punctate red lipid droplets if examined in Oil red O-stained sections imaged by fluorescence microscopy $(A)$. If examined using WETSEM technology imaged by low-power electron microscopy (137), lipid droplets appear in strings of punctate white lipid droplets $(B)$. In glutaraldehyde fixed, osmium tetroxide postfixed, and uranylacetate-stained ultra-thin sections examined in transmission electron microscopy, lipid droplets can be observed adjacent to Z-discs and mitochondria in skeletal muscle $(C)$.

lated by PPAR $\alpha-(25,27,134)$ and PPAR $\beta / \delta$ ligands $(21,118)$. It remains uncertain whether PPAR $\gamma$ is also involved, since several investigations present conflicting results (reviewed in Ref. 27).

TIP47. Another member of the PAT protein family is the 47 $\mathrm{kDa}$ protein TIP47 [also known as pp17 (136)]. TIP47 is ubiquitously expressed (26) and shares $43 \%$ homology with ADRP (8). TIP47 gene expression is not regulated by PPAR $y$ $(26,27)$. Originally, TIP47 was described to be a mannose-6phosphate receptor sorting device $(8,29)$. However, knockdown of TIP47 had no effect on mannose-6-phosphate receptors but did affect LD biogenesis, lipid incorporation, and lipid liberation (17). Knocking-out ADRP in human hepatocytes (Huh7) cells or in immortalized fibroblasts derived from ADRP-ablated embryonic cells, resulted in a compensatory increase in TIP47 $(97,131)$.

In contrast to ADRP, cytosolic TIP47 that is not associated with neutral lipids is not degraded but may translocate to nascent LD, allowing LD growth $(87,97,153)$. Studies using freeze fracture followed by Immunogold labeling revealed that TIP47 and ADRP both are indeed extensively found in association with the LD membrane but may also invade the LD (109-111). Thus, TIP47 may have a role in the packaging of neutral lipids into droplets as well $(17,153)$. Exactly how TIP47 exerts its role, especially in skeletal muscle lipid droplet packaging, however, remains to be established.

S3-12. The PAT member family with the lowest sequence homology to the other PAT proteins is S3-12 (117). S3-12 shares a 33-amino acid motif with ADRP and has a protein sequence identity of 50\% with both TIP47 and ADRP (79) but does not have a PAT domain. S3-12 mRNA is induced in early stages of adipocyte differentiation (117) and coats nascent lipid droplets during TAG synthesis in 3T3-L1 adipocytes (151, 154). S3-12 is highly expressed in WAT and to a lesser, but detectable, extent in BAT, cardiac and skeletal muscle (117).
Transcriptional regulation of S3-12 has been shown to be PPAR $\gamma$ dependent (26). So far, little information is available on the exact role of S3-12 in muscle lipid metabolism.

OXPAT/MLDP/LSDP5. Three independent laboratories recently identified a new PAT domain containing a LD-coating protein expressed mainly in tissues with a high capacity for fat oxidation, like (type 1) muscle fibers, cardiac muscle, brown adipose tissue, and liver. This tissue expression profile resulted in the protein being named OXPAT (152). The same protein has also been identified in the myocardium and was named myocardial lipid droplet protein (MLDP) (158), while a third research group named the protein lipid storage droplet protein (LSDP5) (25). Throughout this review, we will use the name OXPAT. The primary structure of OXPAT shares a high degree of homology to ADRP and TIP47 (25). Importantly, OXPAT has the same PAT domain as the other PAT proteins but has its own unique tissue expression pattern. Via mechanism(s) not yet identified, OXPAT promotes both long-chain fatty acids esterification into TAG, as well as long-chain fatty acid oxidation (152). Because there is a significant overlap in tissues expressing OXPAT and S3-12, it has been suggested that OXPAT and S3-12 are coordinately and reciprocally regulated (152). However, detailed information on the concordant regulation of S3-12 and OXPAT is currently lacking.

Twelve hours of fasting increased OXPAT mRNA, and $24 \mathrm{~h}$ of fasting increased OXPAT protein expression in liver and to a lesser extent in other tissues like the heart. After $12 \mathrm{~h}$ of refeeding, OXPAT mRNA levels had returned to baseline levels (25). Interestingly, in the highly oxidative soleus muscle, the already abundant levels of OXPAT did not respond to fasting or refeeding. Activation of PPAR $\alpha$ induced OXPAT expression in wild-type mice but not in PPAR $\alpha$ knockout mice, suggesting that the presence of PPAR $\alpha$ is required for induction of the OXPAT gene. Fasting increased OXPAT mRNA levels in wild-type mice, but for reasons not yet understood, 
also in the PPAR $\alpha$ knockout animals. It should be noted, though, that because of a considerably lower baseline expression of OXPAT in the PPAR $\alpha$ knockout mice, OXPAT mRNA content, upon fasting, did not reach the levels observed in fed wild-type mice. Thus, it can be concluded that fasting-induced increases in OXPAT expression do not require a functional PPAR $\alpha$ gene, whereas functional PPAR $\alpha$ is important for basal expression of OXPAT in the liver and heart $(25,152$, 158) Interestingly, mice and humans treated with pioglitazone (a PPAR $\gamma$ agonist with PPAR $\alpha$ affinity) increased gene expression of OXPAT in adipose tissue but not in skeletal muscle (152). Recently, we showed that in skeletal muscle from humans that OXPAT protein content in obese control subjects was comparable to levels found in body mass index (BMI)matched type 2 diabetic patients. Interestingly, we also showed that upon rosiglitazone-induced insulin sensitization, OXPAT levels declined significantly without changes in myocellular LD content (86).

Lipid droplet-binding proteins not related to the PAT family. Full activation of ATGL requires interaction of a coactivator known as CGI-58, which, in turn, interacts with perilipin and ADRP on the surface of LD in 3T3-L1 cells $(41,130,159-$ 161). It has been hypothesized that physical association of ATGL with CGI-58 requires release of CGI-58 from the (adipocyte) droplet to exert full lipolytic activity of ATGL $(130,160)$. Experimental data in 3T3-L1 adipocytes indicate that in the basal condition, CGI-58 strongly interacts with perilipin. Upon phosphorylation of perilipin, CGI-58 detaches from perilipin and is released from the droplet to translocate and interact with ATGL at the surface of small LD at sites devoid of perilipin (41).

Given the ubiquitous expression of CGI-58 and the multiple tissues expressing ATGL, it is likely that activation of TG hydrolysis by ATGL and its coactivation by CGI-58 is not restricted to adipose tissue, but it is also operational in, for example, cardiac and skeletal muscle. The notion that CGI-58 might also be operational in skeletal muscle is substantiated by the observations that patients suffering from mutations in either the CGI-58 gene or in the ATGL gene present with severe muscle weakness and myopathies $(3,66)$. As perilipin is not present in muscle tissue, coregulation of ATGL by CGI-58 in skeletal muscle most likely involves other (PAT) protein(s). Indeed, it has recently been shown in mouse cardiac myocytes that in virtually all OXPAT-containing LD also, CGI-58 was detected. In LD, mainly coated by ADRP, no such interaction was observed. Loading cardiac myocytes with oleate promoted interaction of OXPAT with CGI-58 and appeared critical in regulating ATGL lipolytic activity in OXPAT containing LD (42).

By detailed examination of multiple proteins undergoing major changes in expression during adipogenesis, two members of the Cide domain-coating proteins, CideA and $\mathrm{CideC}$ (also known as fat-specific protein 27, FSP27), have recently been identified as LD-binding proteins $(62,95,106,107,138)$. These proteins appear to be involved in the negative regulation of lipolysis and, hence, in LD morphology and LD dynamics in a perilipin-like manner (106). Ectopically overexpressed CideC colocalizes to perilipin (106), suggesting interaction of both proteins in facilitating LD lipolysis.

CideA is predominantly expressed in BAT, with small amounts of mRNA detected in among others cardiac and skeletal muscle. CideC is more widespread, with high levels in WAT and moderate levels in BAT and skeletal muscle (155). Overexpression of CideA and CideC blunts lipid droplet degradation and results in increased ectopic fat storage (106). Downregulation of CideA using RNAi markedly elevates lipolysis in human adipocytes (107). Transcriptional rate of both CideA and CideC is controlled by PPAR $\gamma$. Hence, treating mice with rosiglitazone induced CideA gene expression and lipid deposition in WAT (107). In humans, expression of CideA and CideC correlates positively with insulin sensitivity. A third member of this family, Cide B appears to be involved in hepatic fat storage. Indeed, Cide B knockout mice possessed reduced high-fat diet-induced hepatic steatosis and lower circulatory plasma TGs, and they were insulin sensitive (75).

In search for binding proteins to pigment epithelium-derived factors (PEDF), Notari et al. (96) serendipitously identified ATGL as a PEDF binding protein, where ATGL exerts lipase activity to phospholipids (96). Interestingly, PEDF coprecipitates with ATGL in hepatocytes (22), and the lack of PEDF with subsequent reintroduction was associated with significant increases in steatosis and normalization toward control values, respectively (22). Thus, via binding to ATGL, PEDF may have a role in hepatic triglyceride homeostasis, and, hence, insulin sensitivity. Indeed, it has recently been shown that administrating PEDF to mice stimulated adipose tissue lipolysis, augmented ectopic lipid deposition, and reduced insulin sensitivity. On the other hand, antibody-based neutralization of PEDF in obese mice enhanced insulin sensitivity (24). Overall, these results identify a causal role for PEDF in obesity-induced insulin resistance.

At this stage, it seems safe to conclude that next to the PAT proteins, other proteins with a role in LD dynamics start to emerge. It is, however, not yet fully understood how these proteins may interact to exert their role in modulation of LD dynamics.

\section{Lipid Droplet Formation}

Information on formation, maturation, and potential trafficking of LD in different cell types or tissues is still fragmentary and not always consistent. As reviewed by several authors (16, $82,92,93,150$ ), it has been hypothesized that neutral lipids are deposited between the leaflets of the ER membrane and then budded into the cytoplasm to form a primordial LD. LDcoating proteins might be either integral ER membrane proteins or may be added to the growing LD from the cytosol. Proteins coating the LD may originate from proteins resident in the cytoplasmic leaflet of ER membranes $(16,99)$. In contrast it has been shown that the fatty acid composition of LD phospholipids differed from that of rough ER phospholipids (135), reducing the likeliness that these droplets indeed originally budded from the ER. Alternatively, LD may be formed at specialized ADRP-enriched domains on the cytoplasmic surface of the ER (108).

At present, none of the existing models fully explains how TAG is incorporated into ER-associated LD.

Lipid droplet growth. Upon formation, LD continue to grow until they reach their mature size and the amount of TAG in the $\mathrm{LD}$ increases. The rate-limiting enzyme in TAG synthesis is diacylglycerol acyl-transferase (DGAT), which converts DAG into TAG. Hence, the involvement of DGAT in TAG accretion 
in the LD and increased LD size is anticipated (see Fig. 2). DGAT is present in two isoforms. DGAT1 and DGAT2 both have been located to the ER, albeit at distinct regions $(18,19)$. Fluorescence microscopy of polyene-labeled lipids revealed the presence of DAG to the outside of LD in COS7 cells (70). It has been shown that DGAT2 localizes to the ER under basal conditions and was targeted to the surface of LD in COS7 cells upon oleate loading (129) and that endogenous DGAT2 was localized to the vicinity of LD in 3T3-L1 adipocytes (70). This model is compatible with the origin of LD from the ER and demonstrates that LD can grow in size by inflow of TAG synthesized by DGAT2. Whether DGAT2 and DAG also localize to the LD in other cell types than fibroblasts and adipocytes and how newly formed TAG enters the lipid droplet is not yet known.

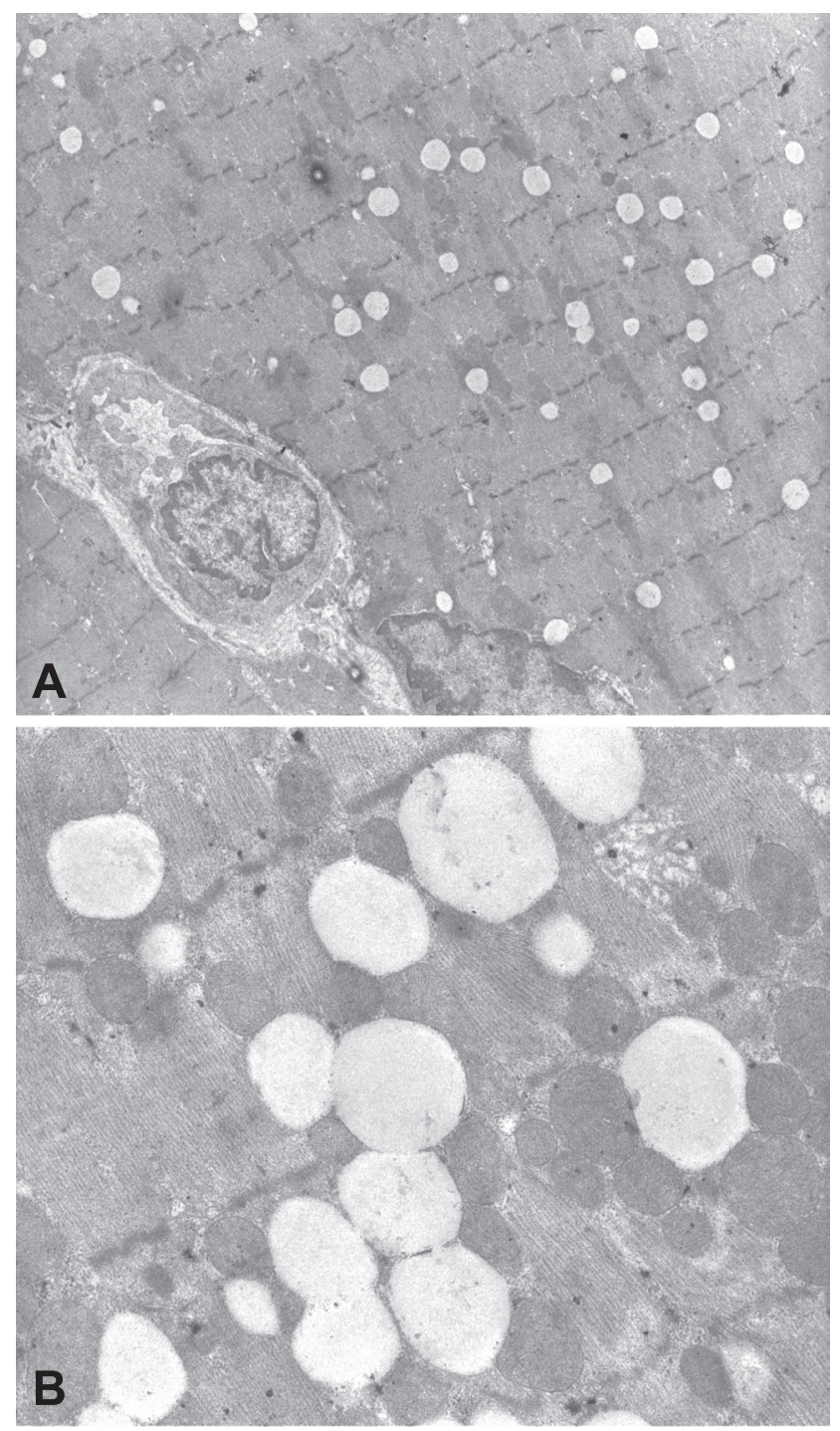

Fig. 2. Transmission electron microscopy image of glutaraldehyde-fixed, osmium tetroxide postfixed, epon-embedded, and uranylacetate-stained ultrathin section of muscle overexpressing diacylglycerol acyl-transferase 1, along with consumption of a high-fat diet (113). This model resulted in large lipid droplets (LD) scattered throughout the muscle cell (A), and some LD appear physically very close or even interconnected, creating the physical condition for LD fusion $(B)$.
Recently, Olofsson et al. (11) hypothesized that primordial droplets are trafficking in the cytosol and fuse in vicinity of other LD (11). Fusion of LD requires membrane fusion of the lipid droplet-coating phospholipid monolayers, in a process facilitated by SNAP23 (11). Physical interaction of myocellular LD under TAG-storing conditions (DGAT 1 overexpression combined with a high-fat diet) is shown in Fig. $2 B$. Interestingly, fusion of GLUT4-containing vesicles with the sarcolemma upon insulin stimulation also requires SNAP23 [for review, see Huang and Czech (53)]. Increasing the amount of SNAP23 to the membrane of LD upon oleate loading resulted in reduced GLUT4 fusion with the sarcolemma, possibly due to the low levels of SNAP remaining for GLUT4 membrane fusion (11). In line with this, overexpressing SNAP23 rescued oleate-mediated insulin resistance (11).

Involvement of PAT proteins in trafficking of LD has been hypothesized and partly been proven by Wolins et al. (150). In his model, PAT proteins are classified on the basis of their stability if not bound to neutral lipids (150). Perilipin and ADRP can be classified as proteins requiring neutral lipids to maintain stability in the absence of neutral lipids. Perilipin and ADRP are degraded via the ubiquitin/proteasome $(156,157)$. Tip47, S3-12, and OXPAT, on the other hand, are situated in the cytosolic pool under nonlipid-loading conditions and may translocate to nascent LD upon lipid loading (150). In line with this, in 3T3-L1 cells incubated with long-chain fatty acids, TAG-filled droplets coated with TIP47, S3-12, and ADRP appear. Subsequently, S3-12 and TIP47 coat the smallest and most peripheral LD, whereas ADRP coats a more medial population of larger LD (151, 154), and the largest droplets are coated with perilipin. Although part of this hypothesis has been confirmed in adipocytes, it should be noted that only adipocytes express all five members of the PAT family at significant levels. Most other cell types express two, or at most three PAT proteins.

\section{Lipid Droplet Dynamics and Insulin Resistance}

Obviously, tight interaction of PAT proteins and well-balanced activity of lipases is required to effectively store fatty acids in LD in times of lipid overflow and for controlled release of fatty acids in times of enhanced demand. Dysregulation of any of these processes might lead to disturbed LD synthesis and/or LD degradation, resulting in a rise in insulin-desensitizing intermediates. It is, therefore, of importance to improve our understanding of regulation of lipid synthesis and degradation in ectopically stored LD and the proteins involved. This type of information in humans, and especially in patient populations, is largely lacking and mainly associative. For example, lower perilipin protein levels have been reported in adipose tissue from obese vs. lean women $(91,144)$. Another study investigated the relation between ADRP and insulin sensitivity in skeletal muscle after a weight loss intervention program and after a pharmacological intervention program with troglitazone (103). Although a correlation between ADRP and insulin sensitivity was not detectable at baseline, ADRP in skeletal muscle was significantly increased after treatment and correlated with improved insulin sensitivity (103). Furthermore, a population of 85 nondiabetic subjects with a wide range of BMI and insulin sensitivity was investigated, and a negative correlation between OXPAT gene expression in adi- 
pose tissue and BMI was found (152). From these data, cause and consequence cannot be separated, and other processes, which were not examined, may also contribute to, or even cause, the observed correlation between OXPAT and BMI (152).

\section{Perspective and Significance}

For decades, intracellular lipid droplets (LD) in nonadipose tissue have been considered to be relatively inert sites of fat storage, which are well preserved across species and can be found in a wide variety of sizes and quantities in various tissues. In lipid bodies in adipocytes, however, it has been recognized that synthesis and degradation of lipid in LD are fairly dynamic processes. Predominantly arising from reports in adipocytes and progress in the imaging of lipid droplets in live cells, the body of knowledge on LD dynamics and the proteins involved have rapidly expanded recently. Defects in LD dynamics have been linked to multiple disorders in lipid and lipoprotein metabolism and may contribute to the insulindesensitizing effects of lipid intermediates (partly originating from LD), in insulin-responsive tissues like adipose tissue, liver, and cardiac and skeletal muscle.

Hydrolysis of lipid stored in LD is catalyzed by the concerted action of distinct lipases, which differ in their affinity for triacyl-, diacyl- or monoacylglycerol. In muscle, the two most abundant and best described lipases identified so far are HSL and ATGL. These lipases regulate-both positively and negatively - the rate of lipolysis by tight cooperation with a family of structurally related lipid droplet-coating proteins (perilipin, ADRP, TIP47, S3-12, and OXPAT, collectively referred to as PAT proteins) and with coactivators like CGI-58. While expression of perilipin appears to be restricted to adipose tissue, the other PAT proteins can be found in other cell types as well. Adrenergic stimulated lipolysis in adipose tissues results in PKA-mediated phosphorylation of perilipin, which recruits HSL to the LD surface to stimulate lipolysis. In addition, PKA activation results in dissociation of CGI-58 from the LD in a perilipin-dependent manner, allowing ATGL-based lipolysis. Prolonged PKA-mediated lipolysis results in smaller LD decorated with ADRP, TIP47, and S3-12.

While interaction of CGI-58 with ADRP has been described as well, it remains unclear whether and in which tissues this interaction affects lipolytic rate. In muscle, interaction of OXPAT with CGI-58 appears to be critical in regulating lipolytic activity of ATGL, but more work is needed to test to what extent information derived from other tissues or cell types can be translated toward (human) skeletal muscle.

Our knowledge on involvement of PAT proteins and their putative interaction with lipases in the regulation of lipolysis of lipid droplets has rapidly expanded. In addition, the emerging body of knowledge from cell studies toward LD growth and fusion expands the field to further explore the mechanisms involved in (dys)regulation of LD dynamics in ectopically stored fat in insulin-responsive tissues like liver and (skeletal) muscle. With this area of research developing, targets to modulate ectopic fat storage, in terms of synthesis, degradation, and lipid turnover, may be identified in the near future that may shed new light on routes to rescue myocellular insulin resistance, the hallmark in the development of overt type 2 diabetes.

\section{ACKNOWLEDGMENTS}

M. Hesselink and R. Meex were appointed on a ZON-MW VIDI Grant 917.66.359 (to M. Hesselink) for innovative research. The skillful technical assistance of Ronnie Minnaard, Gert Schaart, and Hans Duimel in preparing and grabbing the images depicted in Fig. 2 is highly acknowledged.

\section{REFERENCES}

1. Aboulaich N, Vener AV, Stralfors P. Hormonal control of reversible translocation of perilipin B to the plasma membrane in primary human adipocytes. J Biol Chem 281: 11446-11449, 2006.

2. Abumrad NA, Tepperman HM, Tepperman J. Control of endogenous triglyceride breakdown in the mouse diaphragm. J Lipid Res 21: 149$155,1980$.

3. Akiyama M, Sakai K, Ogawa M, McMillan JR, Sawamura D, Shimizu H. Novel duplication mutation in the patatin domain of adipose triglyceride lipase (PNPLA2) in neutral lipid storage disease with severe myopathy. Muscle Nerve 36: 856-859, 2007.

4. Alsted TJ, Nybo L, Schweiger M, Fledelius C, Jacobsen P, Zimmermann R, Zechner R, Kiens B. Adipose triglyceride lipase in human skeletal muscle is upregulated by exercise training. Am J Physiol Endocrinol Metab 296: E445-E453, 2009.

5. Anthonsen MW, Ronnstrand L, Wernstedt C, Degerman E, Holm C. Identification of novel phosphorylation sites in hormone-sensitive lipase that are phosphorylated in response to isoproterenol and govern activation properties in vitro. J Biol Chem 273: 215-221, 1998.

6. Arimura N, Horiba T, Imagawa M, Shimizu M, Sato R. The peroxisome proliferator-activated receptor gamma regulates expression of the perilipin gene in adipocytes. J Biol Chem 279: 10070-10076, 2004.

7. Athenstaedt K, Daum G. Tgl4p and Tg15p, two triacylglycerol lipases of the yeast Saccharomyces cerevisiae are localized to lipid particles. J Biol Chem 280: 37301-37309, 2005.

8. Barbero P, Buell E, Zulley S, Pfeffer SR. TIP47 is not a component of lipid droplets. J Biol Chem 276: 24348-24351, 2001.

9. Berndt J, Kralisch S, Kloting N, Ruschke K, Kern M, Fasshauer M, Schon MR, Stumvoll M, Bluher M. Adipose triglyceride lipase gene expression in human visceral obesity. Exp Clin Endocrinol Diabetes 116: 203-210, 2008.

10. Blanchette-Mackie EJ, Dwyer NK, Barber T, Coxey RA, Takeda T, Rondinone CM, Theodorakis JL, Greenberg AS, Londos C. Perilipin is located on the surface layer of intracellular lipid droplets in adipocytes. J Lipid Res 36: 1211-1226, 1995.

11. Bostrom P, Andersson L, Rutberg M, Perman J, Lidberg U, Johansson BR, Fernandez-Rodriguez J, Ericson J, Nilsson T, Boren J, Olofsson SO. SNARE proteins mediate fusion between cytosolic lipid droplets and are implicated in insulin sensitivity. Nat Cell Biol 9: 1286-1293, 2007.

12. Bostrom P, Rutberg M, Ericsson J, Holmdahl P, Andersson L, Frohman MA, Boren J, Olofsson SO. Cytosolic lipid droplets increase in size by microtubule-dependent complex formation. Arterioscler Thromb Vasc Biol 25: 1945-1951, 2005.

13. Brasaemle DL, Barber T, Wolins NE, Serrero G, Blanchette-Mackie EJ, Londos C. Adipose differentiation-related protein is an ubiquitously expressed lipid storage droplet-associated protein. J Lipid Res 38: 22492263, 1997.

14. Brasaemle DL, Levin DM, Adler-Wailes DC, Londos C. The lipolytic stimulation of 3T3-L1 adipocytes promotes the translocation of hormone-sensitive lipase to the surfaces of lipid storage droplets. Biochim Biophys Acta 1483: 251-262, 2000.

15. Brasaemle DL, Rubin B, Harten IA, Gruia-Gray J, Kimmel AR, Londos C. Perilipin A increases triacylglycerol storage by decreasing the rate of triacylglycerol hydrolysis. J Biol Chem 275: 38486-38493, 2000.

16. Brown DA. Lipid droplets: proteins floating on a pool of fat. Curr Biol 11: R446-449, 2001.

17. Bulankina AV, Deggerich A, Wenzel D, Mutenda K, Wittmann JG, Rudolph MG, Burger KN, Honing S. TIP47 functions in the biogenesis of lipid droplets. J Cell Biol 185: 641-655, 2009.

18. Cases S, Smith SJ, Zheng YW, Myers HM, Lear SR, Sande E, Novak S, Collins C, Welch CB, Lusis AJ, Erickson SK, Farese RV Jr. Identification of a gene encoding an acyl CoA:diacylglycerol acyltransferase, a key enzyme in triacylglycerol synthesis. Proc Natl Acad Sci USA 95: 13018-13023, 1998.

19. Cases S, Stone SJ, Zhou P, Yen E, Tow B, Lardizabal KD, Voelker T, Farese RV Jr. Cloning of DGAT2, a second mammalian diacylglyc- 
erol acyltransferase, and related family members. J Biol Chem 276: 38870-38876, 2001.

20. Chang BH, Li L, Paul A, Taniguchi S, Nannegari V, Heird WC, Chan L. Protection against fatty liver but normal adipogenesis in mice lacking adipose differentiation-related protein. Mol Cell Biol 26: 10631076, 2006

21. Chawla A, Lee CH, Barak Y, He W, Rosenfeld J, Liao D, Han J, Kang H, Evans RM. PPAR $\delta$ is a very low-density lipoprotein sensor in macrophages. Proc Natl Acad Sci USA 100: 1268-1273, 2003.

22. Chung C, Doll JA, Gattu AK, Shugrue C, Cornwell M, Fitchev P, Crawford SE. Anti-angiogenic pigment epithelium-derived factor regulates hepatocyte triglyceride content through adipose triglyceride lipase (ATGL). J Hepatol 48: 471-478, 2008.

23. Clifford GM, Londos C, Kraemer FB, Vernon RG, Yeaman SJ. Translocation of hormone-sensitive lipase and perilipin upon lipolytic stimulation of rat adipocytes. J Biol Chem 275: 5011-5015, 2000.

24. Crowe S, Wu LE, Economou C, Turpin SM, Matzaris M, Hoehn KL, Hevener AL, James DE, Duh EJ, Watt MJ. Pigment epitheliumderived factor contributes to insulin resistance in obesity. Cell Metab 10: 40-47, 2009

25. Dalen KT, Dahl T, Holter E, Arntsen B, Londos C, Sztalryd C, Nebb HI. LSDP5 is a PAT protein specifically expressed in fatty acid oxidizing tissues. Biochim Biophys Acta 1771: 210-227, 2007.

26. Dalen KT, Schoonjans K, Ulven SM, Weedon-Fekjaer MS, Bentzen TG, Koutnikova H, Auwerx J, Nebb HI. Adipose tissue expression of the lipid droplet-associating proteins S3-12 and perilipin is controlled by peroxisome proliferator-activated receptor-gamma. Diabetes 53: 12431252,2004

27. Dalen KT, Ulven SM, Arntsen BM, Solaas K, Nebb HI. PPAR $\alpha$ activators and fasting induce the expression of adipose differentiationrelated protein in liver. J Lipid Res 47: 931-943, 2006.

28. Degerman E, Landstrom TR, Wijkander J, Holst LS, Ahmad F, Belfrage P, Manganiello V. Phosphorylation and activation of hormonesensitive adipocyte phosphodiesterase type 3B. Methods 14: 43-53, 1998.

29. Diaz E, Pfeffer SR. TIP47: a cargo selection device for mannose 6-phosphate receptor trafficking. Cell 93: 433-443, 1998.

30. Donsmark M, Langfort J, Holm C, Ploug T, Galbo H. Contractions activate hormone-sensitive lipase in rat muscle by protein kinase $\mathrm{C}$ and mitogen-activated protein kinase. J Physiol 550: 845-854, 2003.

31. Eastmond PJ. SUGAR-DEPENDENT1 encodes a patatin domain triacylglycerol lipase that initiates storage oil breakdown in germinating Arabidopsis seeds. Plant Cell 18: 665-675, 2006.

32. Egan JJ, Greenberg AS, Chang MK, Londos C. Control of endogenous phosphorylation of the major cAMP-dependent protein kinase substrate in adipocytes by insulin and beta-adrenergic stimulation. J Biol Chem 265: 18769-18775, 1990.

33. Egan JJ, Greenberg AS, Chang MK, Wek SA, Moos MC Jr, Londos C. Mechanism of hormone-stimulated lipolysis in adipocytes: translocation of hormone-sensitive lipase to the lipid storage droplet. Proc Natl Acad Sci USA 89: 8537-8541, 1992.

34. Eisinger DP, Serrero G. Structure of the gene-encoding mouse adipose differentiation-related protein (ADRP). Genomics 16: 638-644, 1993.

35. Fischer J, Lefevre C, Morava E, Mussini JM, Laforet P, NegreSalvayre A, Lathrop M, Salvayre R. The gene encoding adipose triglyceride lipase (PNPLA2) is mutated in neutral lipid storage disease with myopathy. Nat Genet 39: 28-30, 2007.

36. Fredrikson G, Stralfors P, Nilsson NO, Belfrage P. Hormone-sensitive lipase of rat adipose tissue. Purification and some properties. J Biol Chem 256: 6311-6320, 1981

37. Fredrikson G, Tornqvist H, Belfrage P. Hormone-sensitive lipase and monoacylglycerol lipase are both required for complete degradation of adipocyte triacylglycerol. Biochim Biophys Acta 876: 288-293, 1986.

38. Gao J, Serrero G. Adipose differentiation related protein (ADRP) expressed in transfected COS-7 cells selectively stimulates long-chain fatty acid uptake. J Biol Chem 274: 16825-16830, 1999.

39. Garcia A, Subramanian V, Sekowski A, Bhattacharyya S, Love MW, Brasaemle DL. The amino and carboxyl termini of perilipin a facilitate the storage of triacylglycerols. J Biol Chem 279: 8409-8416, 2004.

40. Goodpaster BH, He J, Watkins S, Kelley DE. Skeletal muscle lipid content and insulin resistance: evidence for a paradox in endurancetrained athletes. J Clin Endocrinol Metab 86: 5755-5761, 2001.
41. Granneman JG, Moore HP, Granneman RL, Greenberg AS, Obin MS, Zhu Z. Analysis of lipolytic protein trafficking and interactions in adipocytes. J Biol Chem 282: 5726-5735, 2007.

42. Granneman JG, Moore HP, Mottillo EP, Zhu Z. Functional interactions between Mldp (LSDP5) and Abhd5 in the control of intracellular lipid accumulation. J Biol Chem 284: 3049-3057, 2009.

43. Greenberg AS, Egan JJ, Wek SA, Garty NB, Blanchette-Mackie EJ, Londos C. Perilipin, a major hormonally regulated adipocyte-specific phosphoprotein associated with the periphery of lipid storage droplets. J Biol Chem 266: 11341-11346, 1991.

44. Greenberg AS, Egan JJ, Wek SA, Moos MC Jr, Londos C, Kimmel AR. Isolation of cDNAs for perilipins A and B: sequence and expression of lipid droplet-associated proteins of adipocytes. Proc Natl Acad Sci USA 90: 12035-12039, 1993.

45. Greenberg AS, Shen WJ, Muliro K, Patel S, Souza SC, Roth RA, Kraemer FB. Stimulation of lipolysis and hormone-sensitive lipase via the extracellular signal-regulated kinase pathway. J Biol Chem 276: 45456-45461, 2001.

46. Gronke S, Mildner A, Fellert S, Tennagels N, Petry S, Muller G, Jackle H, Kuhnlein RP. Brummer lipase is an evolutionary conserved fat storage regulator in Drosophila. Cell Metab 1: 323-330, 2005.

47. Haemmerle G, Lass A, Zimmermann R, Gorkiewicz G, Meyer C, Rozman J, Heldmaier G, Maier R, Theussl C, Eder S, Kratky D, Wagner EF, Klingenspor M, Hoefler G, Zechner R. Defective lipolysis and altered energy metabolism in mice lacking adipose triglyceride lipase. Science 312: 734-737, 2006.

48. Haemmerle G, Zimmermann R, Hayn M, Theussl C, Waeg G, Wagner E, Sattler W, Magin TM, Wagner EF, Zechner R, van Ea. Hormone-sensitive lipase deficiency in mice causes diglyceride accumulation in adipose tissue, muscle, and testis. J Biol Chem 277: 4806-4815, 2002.

49. He J, Goodpaster BH, Kelley DE. Effects of weight loss and physical activity on muscle lipid content and droplet size. Obes Res 12: 761-769, 2004.

50. Heid HW, Moll R, Schwetlick I, Rackwitz HR, Keenan TW. Adipophilin is a specific marker of lipid accumulation in diverse cell types and diseases. Cell Tissue Res 294: 309-321, 1998.

51. Holm C, Kirchgessner TG, Svenson KL, Fredrikson G, Nilsson S, Miller CG, Shively JE, Heinzmann C, Sparkes RS, Mohandas T. Hormone-sensitive lipase: sequence, expression, and chromosomal localization to 19 cent-q133. Science 241: 1503-1506, 1988.

52. Holm C, Osterlund T, Laurell H, Contreras JA. Molecular mechanisms regulating hormone-sensitive lipase and lipolysis. Anпи Rev Nutr 20: $365-393,2000$

53. Huang S, Czech MP. The GLUT4 glucose transporter. Cell Metab 5: $237-252,2007$

54. Huijsman E, van de Par C, Economou C, van der Poel C, Lynch GS, Schoiswohl G, Haemmerle G, Zechner R, Watt MJ. Adipose triacylglycerol lipase deletion alters whole body energy metabolism and impairs exercise performance in mice. Am J Physiol Endocrinol Metab 297: E505-E513, 2009.

55. Imai Y, Varela GM, Jackson MB, Graham MJ, Crooke RM, Ahima RS. Reduction of hepatosteatosis and lipid levels by an adipose differentiation-related protein antisense oligonucleotide. Gastroenterology 132: 1947-1954, 2007

56. Itani SI, Ruderman NB, Schmieder F, Boden G. Lipid-induced insulin resistance in human muscle is associated with changes in diacylglycerol, protein kinase C, and IкB-alpha. Diabetes 51: 2005-2011, 2002.

57. Jacob S, Machann J, Rett K, Brechtel K, Volk A, Renn W, Maerker E, Matthaei S, Schick F, Claussen CD, Haring HU. Association of increased intramyocellular lipid content with insulin resistance in lean nondiabetic offspring of type 2 diabetic subjects. Diabetes 48: 1113$1119,1999$.

58. Jenkins CM, Mancuso DJ, Yan W, Sims HF, Gibson B, Gross RW. Identification, cloning, expression, and purification of three novel human calcium-independent phospholipase A2 family members possessing triacylglycerol lipase and acylglycerol transacylase activities. J Biol Chem 279: 48968-48975, 2004.

59. Jiang HP, Serrero G. Isolation and characterization of a full-length cDNA coding for an adipose differentiation-related protein. Proc Natl Acad Sci USA 89: 7856-7860, 1992.

60. Jocken JW, Blaak EE. Catecholamine-induced lipolysis in adipose tissue and skeletal muscle in obesity. Physiol Behav 94: 219-230, 2008. 
61. Jocken JW, Langin D, Smit E, Saris WH, Valle C, Hul GB, Holm C, Arner P, Blaak EE. Adipose triglyceride lipase (ATGL) and hormonesensitive lipase (HSL) protein expression is decreased in the obese insulin-resistant state. J Clin Endocrinol Metab 92: 2292-2299, 2007.

62. Keller P, Petrie JT, De Rose P, Gerin I, Wright WS, Chiang SH, Nielsen AR, Fischer CP, Pedersen BK, MacDougald OA. Fat-specific protein 27 regulates storage of triacylglycerol. J Biol Chem 283: 1435514365,2008

63. Kershaw EE, Hamm JK, Verhagen LA, Peroni O, Katic M, Flier JS. Adipose triglyceride lipase: function, regulation by insulin, and comparison with adiponutrin. Diabetes 55: 148-157, 2006.

64. Kershaw EE, Schupp M, Guan HP, Gardner NP, Lazar MA, Flier JS. PPAR $\gamma$ regulates adipose triglyceride lipase in adipocytes in vitro and in vivo. Am J Physiol Endocrinol Metab 293: E1736-E1745, 2007.

65. Kim JY, Tillison K, Lee JH, Rearick DA, Smas C. The adipose tissue triglyceride lipase ATGL/PNPLA2 is downregulated by insulin and TNF $\alpha$ in 3T3-L1 adipocytes and is a target for transactivation by PPARy. Am J Physiol Endocrinol Metab 291: E115-E127, 2006.

66. Kobayashi K, Inoguchi T, Maeda Y, Nakashima N, Kuwano A, Eto E, Ueno N, Sasaki S, Sawada F, Fujii M, Matoba Y, Sumiyoshi S, Kawate H, Takayanagi R. The lack of the C-terminal domain of adipose triglyceride lipase causes neutral lipid storage disease through impaired interactions with lipid droplets. J Clin Endocrinol Metab 93: 2877-2884, 2008.

67. Kraemer FB, Patel S, Saedi MS, Sztalryd C. Detection of hormonesensitive lipase in various tissues. I. Expression of an HSL/bacterial fusion protein and generation of anti-HSL antibodies. J Lipid Res 34: 663-671, 1993.

68. Kralisch S, Klein J, Lossner U, Bluher M, Paschke R, Stumvoll M, Fasshauer M. Isoproterenol, TNF $\alpha$, and insulin downregulate adipose triglyceride lipase in 3T3-L1 adipocytes. Mol Cell Endocrinol 240: 43-49, 2005.

69. Krssak M, Falk Petersen K, Dresner A, DiPietro L, Vogel SM, Rothman DL, Roden M, Shulman GI. Intramyocellular lipid concentrations are correlated with insulin sensitivity in humans: a $1 \mathrm{H}$ NMR spectroscopy study. Diabetologia 42: 113-116, 1999.

70. Kuerschner L, Moessinger $\mathbf{C}$, Thiele $\mathbf{C}$. Imaging of lipid biosynthesis: how a neutral lipid enters lipid droplets. Traffic 9: 338-352, 2008.

71. Lake AC, Sun Y, Li JL, Kim JE, Johnson JW, Li D, Revett T, Shih HH, Liu W, Paulsen JE, Gimeno RE. Expression, regulation, and triglyceride hydrolase activity of Adiponutrin family members. J Lipid Res 46: 2477-2487, 2005.

72. Langfort J, Ploug T, Ihlemann J, Saldo M, Holm C, Galbo H. Expression of hormone-sensitive lipase and its regulation by adrenaline in skeletal muscle. Biochem J 340: 459-465, 1999.

73. Langin D, Dicker A, Tavernier G, Hoffstedt J, Mairal A, Ryden M, Arner E, Sicard A, Jenkins CM, Viguerie N, van Harmelen V, Gross RW, Holm C, Arner P. Adipocyte lipases and defect of lipolysis in human obesity. Diabetes 54: 3190-3197, 2005

74. Lass A, Zimmermann R, Haemmerle G, Riederer M, Schoiswohl G, Schweiger M, Kienesberger P, Strauss JG, Gorkiewicz G, Zechner R. Adipose triglyceride lipase-mediated lipolysis of cellular fat stores is activated by CGI-58 and defective in Chanarin-Dorfman Syndrome. Cell Metab 3: 309-319, 2006.

75. Li JZ, Ye J, Xue B, Qi J, Zhang J, Zhou Z, Li Q, Wen Z, Li P. Cideb regulates diet-induced obesity, liver steatosis, and insulin sensitivity by controlling lipogenesis and fatty acid oxidation. Diabetes 56: 2523-2532, 2007.

76. Listenberger LL, Ostermeyer-Fay AG, Goldberg EB, Brown WJ, Brown DA. Adipocyte differentiation-related protein reduces lipid droplet association of adipose triglyceride lipase and slows triacylglycerol turnover. J Lipid Res 48: 2751-2761, 2007.

77. Liu LF, Purushotham A, Wendel AA, Koba K, DeIuliis J, Lee K, Belury MA. Regulation of adipose triglyceride lipase by rosiglitazone. Diabetes Obes Metab 11: 131-142, 2009.

78. Londos C, Honnor RC, Dhillon GS. cAMP-dependent protein kinase and lipolysis in rat adipocytes. III. Multiple modes of insulin regulation of lipolysis and regulation of insulin responses by adenylate cyclase regulators. J Biol Chem 260: 15139-15145, 1985.

79. Lu X, Gruia-Gray J, Copeland NG, Gilbert DJ, Jenkins NA, Londos C, Kimmel AR. The murine perilipin gene: the lipid droplet-associated perilipins derive from tissue-specific, mRNA splice variants and define a gene family of ancient origin. Mamm Genome 12: 741-749, 2001
80. Magnusson B, Asp L, Bostrom P, Ruiz M, Stillemark-Billton P, Linden D, Boren J, Olofsson SO. Adipocyte differentiation-related protein promotes fatty acid storage in cytosolic triglycerides and inhibits secretion of very low-density lipoproteins. Arterioscler Thromb Vasc Biol 26: 1566-1571, 2006.

81. Mairal A, Langin D, Arner P, Hoffstedt J. Human adipose triglyceride lipase (PNPLA2) is not regulated by obesity and exhibits low in vitro triglyceride hydrolase activity. Diabetologia 49: 1629-1636, 2006.

82. Martin S, Parton RG. Lipid droplets: a unified view of a dynamic organelle. Nat Rev Mol Cell Biol 7: 373-378, 2006.

83. Martinez-Botas J, Anderson JB, Tessier D, Lapillonne A, Chang BH, Quast MJ, Gorenstein D, Chen KH, Chan L. Absence of perilipin results in leanness and reverses obesity in $\operatorname{Lepr}(\mathrm{db} / \mathrm{db})$ mice. Nat Genet 26: 474-479, 2000.

84. Masuda Y, Itabe H, Odaki M, Hama K, Fujimoto Y, Mori M, Sasabe N, Aoki J, Arai H, Takano T. ADRP/adipophilin is degraded through the proteasome-dependent pathway during regression of lipid-storing cells. J Lipid Res 47: 87-98, 2006.

85. McManaman JL, Zabaronick W, Schaack J, Orlicky DJ. Lipid droplet targeting domains of adipophilin. J Lipid Res 44: 668-673, 2003.

86. Minnaard R, Schrauwen P, Schaart G, Jorgensen JA, Lenaers E, Mensink M, Hesselink MKC. Adipocyte differentiation-related protein and OXPAT in rat and human skeletal muscle: involvement in lipid accumulation and Type 2 diabetes mellitus. In Press.

87. Miura S, Gan JW, Brzostowski J, Parisi MJ, Schultz CJ, Londos C, Oliver B, Kimmel AR. Functional conservation for lipid storage droplet association among Perilipin, ADRP, and TIP47 (PAT)-related proteins in mammals, Drosophila, and Dictyostelium. J Biol Chem 277: 3225332257, 2002

88. Miyoshi H, Souza SC, Zhang HH, Strissel KJ, Christoffolete MA, Kovsan J, Rudich A, Kraemer FB, Bianco AC, Obin MS, Greenberg AS. Perilipin promotes hormone-sensitive lipase-mediated adipocyte lipolysis via phosphorylation-dependent and -independent mechanisms. J Biol Chem 281: 15837-15844, 2006.

89. Mooney RA, Bordwell KL. Counter-regulation by insulin and isoprenaline of a prominent fat-associated phosphoprotein doublet in rat adipocytes. Biochem J 274: 433-438, 1991.

90. Motomura W, Inoue M, Ohtake T, Takahashi N, Nagamine M, Tanno S, Kohgo Y, Okumura T. Up-regulation of ADRP in fatty liver in human and liver steatosis in mice fed with high-fat diet. Biochem Biophys Res Commun 340: 1111-1118, 2006.

91. Mottagui-Tabar S, Ryden M, Lofgren P, Faulds G, Hoffstedt J, Brookes AJ, Andersson I, Arner P. Evidence for an important role of perilipin in the regulation of human adipocyte lipolysis. Diabetologia 46: 789-797, 2003

92. Murphy DJ. The biogenesis and functions of lipid bodies in animals, plants and microorganisms. Prog Lipid Res 40: 325-438, 2001.

93. Murphy DJ, Vance J. Mechanisms of lipid-body formation. Trends Biochem Sci 24: 109-115, 1999.

94. Nishino N, Tamori Y, Kasuga M. Insulin efficiently stores triglycerides in adipocytes by inhibiting lipolysis and repressing PGC- $1 \alpha$ induction. Kobe J Med Sci 53: 99-106, 2007.

95. Nishino N, Tamori Y, Tateya S, Kawaguchi T, Shibakusa T, Mizunoya W, Inoue K, Kitazawa R, Kitazawa S, Matsuki Y, Hiramatsu R, Masubuchi S, Omachi A, Kimura K, Saito M, Amo T, Ohta S, Yamaguchi T, Osumi T, Cheng J, Fujimoto T, Nakao H, Nakao K, Aiba A, Okamura H, Fushiki T, Kasuga M. FSP27 contributes to efficient energy storage in murine white adipocytes by promoting the formation of unilocular lipid droplets. J Clin Invest 118: 2808-2821, 2008.

96. Notari L, Baladron V, Aroca-Aguilar JD, Balko N, Heredia R, Meyer C, Notario PM, Saravanamuthu S, Nueda ML, Sanchez-Sanchez F, Escribano J, Laborda J, Becerra SP. Identification of a lipase-linked cell membrane receptor for pigment epithelium-derived factor. $J$ Biol Chem 281: 38022-38037, 2006.

97. Ohsaki Y, Maeda T, Maeda M, Tauchi-Sato K, Fujimoto T. Recruitment of TIP47 to lipid droplets is controlled by the putative hydrophobic cleft. Biochem Biophys Res Commun 347: 279-287, 2006.

98. Okazaki H, Igarashi M, Nishi M, Tajima M, Sekiya M, Okazaki S, Yahagi N, Ohashi K, Tsukamoto K, Amemiya-Kudo M, Matsuzaka T, Shimano H, Yamada N, Aoki J, Morikawa R, Takanezawa Y, Arai H, Nagai R, Kadowaki T, Osuga J, Ishibashi S. Identification of a novel member of the carboxylesterase family that hydrolyzes triacylglyc- 
erol: a potential role in adipocyte lipolysis. Diabetes 55: 2091-2097, 2006.

99. Ostermeyer AG, Paci JM, Zeng Y, Lublin DM, Munro S, Brown DA. Accumulation of caveolin in the endoplasmic reticulum redirects the protein to lipid storage droplets. J Cell Biol 152: 1071-1078, 2001.

100. Osuga J, Ishibashi S, Oka T, Yagyu H, Tozawa R, Fujimoto A, Shionoiri F, Yahagi N, Kraemer FB, Tsutsumi O, Yamada N. Targeted disruption of hormone-sensitive lipase results in male sterility and adipocyte hypertrophy, but not in obesity. Proc Natl Acad Sci USA 97: 787-792, 2000.

101. Pan DA, Lillioja S, Kriketos AD, Milner MR, Baur LA, Bogardus C, Jenkins AB, Storlien LH. Skeletal muscle triglyceride levels are inversely related to insulin action. Diabetes 46: 983-988, 1997.

102. Paulin D, Li Z. Desmin: a major intermediate filament protein essential for the structural integrity and function of muscle. Exp Cell Res 301: 1-7, 2004.

103. Phillips SA, Choe CC, Ciaraldi TP, Greenberg AS, Kong AP, Baxi SC, Christiansen L, Mudaliar SR, Henry RR. Adipocyte differentiation-related protein in human skeletal muscle: relationship to insulin sensitivity. Obes Res 13: 1321-1329, 2005.

104. Pickersgill L, Litherland GJ, Greenberg AS, Walker M, Yeaman SJ. Key role for ceramides in mediating insulin resistance in human muscle cells. J Biol Chem 282: 12583-12589, 2007.

105. Prats C, Donsmark M, Qvortrup K, Londos C, Sztalryd C, Holm C, Galbo H, Ploug T. Decrease in intramuscular lipid droplets and translocation of HSL in response to muscle contraction and epinephrine. $J$ Lipid Res 47: 2392-2399, 2006.

106. Puri V, Konda S, Ranjit S, Aouadi M, Chawla A, Chouinard M, Chakladar A, Czech MP. Fat specific protein 27: A novel lipid droplet protein that enhances triglyceride storage. J Biol Chem 282: 3421334218, 2007

107. Puri V, Ranjit S, Konda S, Nicoloro SM, Straubhaar J, Chawla A, Chouinard M, Lin C, Burkart A, Corvera S, Perugini RA, Czech MP. Cidea is associated with lipid droplets and insulin sensitivity in humans. Proc Natl Acad Sci USA 105: 7833-7838, 2008.

108. Robenek H, Hofnagel O, Buers I, Robenek MJ, Troyer D, Severs NJ. Adipophilin-enriched domains in the ER membrane are sites of lipid droplet biogenesis. J Cell Sci 119: 4215-4224, 2006.

109. Robenek H, Lorkowski S, Schnoor M, Troyer D. Spatial integration of TIP47 and adipophilin in macrophage lipid bodies. J Biol Chem 280: 5789-5794, 2005.

110. Robenek H, Robenek MJ, Buers I, Lorkowski S, Hofnagel O, Troyer D, Severs NJ. Lipid droplets gain PAT family proteins by interaction with specialized plasma membrane domains. J Biol Chem 280: 2633026338, 2005

111. Robenek H, Robenek MJ, Troyer D. PAT family proteins pervade lipid droplet cores. J Lipid Res 46: 1331-1338, 2005.

112. Roden M, Price TB, Perseghin G, Petersen KF, Rothman DL, Cline GW, Shulman GI. Mechanism of free fatty acid-induced insulin resistance in humans. J Clin Invest 97: 2859-2865, 1996

113. Roorda BD, Hesselink MK, Schaart G, Moonen-Kornips E, Martinez-Martinez P, Losen M, De Baets MH, Mensink RP, Schrauwen P. DGAT1 overexpression in muscle by in vivo DNA electroporation increases intramyocellular lipid content. J Lipid Res 46: 230-236, 2005.

114. Ryden M, Jocken J, van Harmelen V, Dicker A, Hoffstedt J, Wiren M, Blomqvist L, Mairal A, Langin D, Blaak EE, Arner P. Comparative studies of the role of hormone sensitive lipase and adipose triglyceride lipase in human fat cell lipolysis. Am J Physiol Endocrinol Metab 292: E1847-E1855, 2007.

115. Saha PK, Kojima H, Martinez-Botas J, Sunehag AL, Chan L. Metabolic adaptations in the absence of perilipin: increased beta-oxidation and decreased hepatic glucose production associated with peripheral insulin resistance but normal glucose tolerance in perilipin-null mice. J Biol Chem 279: 35150-35158, 2004.

116. Schadinger SE, Bucher NL, Schreiber BM, Farmer SR. PPAR $\gamma 2$ regulates lipogenesis and lipid accumulation in steatotic hepatocytes. Am J Physiol Endocrinol Metab 288: E1195-E1205, 2005.

117. Scherer PE, Bickel PE, Kotler M, Lodish HF. Cloning of cell-specific secreted and surface proteins by subtractive antibody screening. Nat Biotechnol 16: 581-586, 1998.

118. Schmuth M, Haqq CM, Cairns WJ, Holder JC, Dorsam S, Chang S, Lau P, Fowler AJ, Chuang G, Moser AH, Brown BE, Mao-Qiang M, Uchida Y, Schoonjans K, Auwerx J, Chambon P, Willson TM, Elias PM, Feingold KR. Peroxisome proliferator-activated receptor (PPAR)- beta/delta stimulates differentiation and lipid accumulation in keratinocytes. J Invest Dermatol 122: 971-983, 2004.

119. Schrauwen-Hinderling VB, Schrauwen P, Hesselink MK, van Engelshoven JM, Nicolay K, Saris WH, Kessels AG, Kooi ME. The increase in intramyocellular lipid content is a very early response to training. J Clin Endocrinol Metab 88: 1610-1616, 2003.

120. Schweiger M, Schreiber R, Haemmerle G, Lass A, Fledelius C, Jacobsen P, Tornqvist H, Zechner R, Zimmermann R. Adipose triglyceride lipase and hormone-sensitive lipase are the major enzymes in adipose tissue triacylglycerol catabolism. J Biol Chem 281: 4023640241, 2006

121. Shen WJ, Patel S, Yu Z, Jue D, Kraemer FB. Effects of rosiglitazone and high fat diet on lipase/esterase expression in adipose tissue. Biochim Biophys Acta 1771: 177-184, 2007.

122. Shulman GI. Cellular mechanisms of insulin resistance. J Clin Invest 106: 171-176, 2000.

123. Small CA, Goodacre JA, Yeaman SJ. Hormone-sensitive lipase is responsible for the neutral cholesterol ester hydrolase activity in macrophages. FEBS Lett 247: 205-208, 1989.

124. Smirnova E, Goldberg EB, Makarova KS, Lin L, Brown WJ, Jackson CL. ATGL has a key role in lipid droplet/adiposome degradation in mammalian cells. EMBO Rep 7: 106-113, 2006.

125. Souza SC, de Vargas LM, Yamamoto MT, Lien P, Franciosa MD, Moss LG, Greenberg AS. Overexpression of perilipin A and B blocks the ability of tumor necrosis factor alpha to increase lipolysis in 3T3-L1 adipocytes. J Biol Chem 273: 24665-24669, 1998.

126. Souza SC, Muliro KV, Liscum L, Lien P, Yamamoto MT, Schaffer JE, Dallal GE, Wang X, Kraemer FB, Obin M, Greenberg AS. Modulation of hormone-sensitive lipase and protein kinase A-mediated lipolysis by perilipin A in an adenoviral reconstituted system. $J$ Biol Chem 277: 8267-8272, 2002.

127. Steinberg GR, Kemp BE, Watt MJ. Adipocyte triglyceride lipase expression in human obesity. Am J Physiol Endocrinol Metab 293: E958-E964, 2007.

128. Steiner S, Wahl D, Mangold BL, Robison R, Raymackers J, Meheus L, Anderson NL, Cordier A. Induction of the adipose differentiationrelated protein in liver of etomoxir-treated rats. Biochem Biophys Res Commun 218: 777-782, 1996.

129. Stone SJ, Levin MC, Zhou P, Han J, Walther TC, Farese RV Jr. The endoplasmic reticulum enzyme DGAT2 is found in mitochondria-associated membranes and has a mitochondrial targeting signal that promotes its association with mitochondria. J Biol Chem 284: 5352-5361, 2009.

130. Subramanian V, Rothenberg A, Gomez C, Cohen AW, Garcia A, Bhattacharyya S, Shapiro L, Dolios G, Wang R, Lisanti MP, Brasaemle DL. Perilipin A mediates the reversible binding of CGI-58 to lipid droplets in 3T3-L1 adipocytes. J Biol Chem 279: 42062-42071, 2004.

131. Sztalryd C, Bell M, Lu X, Mertz P, Hickenbottom S, Chang BH, Chan L, Kimmel AR, Londos C. Functional compensation for adipose differentiation-related protein (ADFP) by Tip47 in an ADFP null embryonic cell line. J Biol Chem 281: 34341-34348, 2006.

132. Sztalryd C, Xu G, Dorward H, Tansey JT, Contreras JA, Kimmel AR, Londos C. Perilipin A is essential for the translocation of hormonesensitive lipase during lipolytic activation. J Cell Biol 161: 1093-1103, 2003.

133. Tansey JT, Sztalryd C, Gruia-Gray J, Roush DL, Zee JV, Gavrilova O, Reitman ML, Deng CX, Li C, Kimmel AR, Londos C. Perilipin ablation results in a lean mouse with aberrant adipocyte lipolysis, enhanced leptin production, and resistance to diet-induced obesity. Proc Natl Acad Sci USA 98: 6494-6499, 2001.

134. Targett-Adams P, McElwee MJ, Ehrenborg E, Gustafsson MC, Palmer CN, McLauchlan J. A PPAR response element regulates transcription of the gene for human adipose differentiation-related protein. Biochim Biophys Acta 1728: 95-104, 2005.

135. Tauchi-Sato K, Ozeki S, Houjou T, Taguchi R, Fujimoto T. The surface of lipid droplets is a phospholipid monolayer with a unique fatty acid composition. J Biol Chem 277: 44507-44512, 2002.

136. Than NG, Sumegi B, Than GN, Kispal G, Bohn H. Cloning and sequence analysis of cDNAs encoding human placental tissue protein 17 (PP17) variants. Eur J Biochem 258: 752-757, 1998.

137. Thiberge S, Nechushtan A, Sprinzak D, Gileadi O, Behar V, Zik O, Chowers Y, Michaeli S, Schlessinger J, Moses E. Scanning electron microscopy of cells and tissues under fully hydrated conditions. Proc Natl Acad Sci USA 101: 3346-3351, 2004. 
138. Toh SY, Gong J, Du G, Li JZ, Yang S, Ye J, Yao H, Zhang Y, Xue B, Li Q, Yang H, Wen Z, Li P. Up-regulation of mitochondrial activity and acquirement of brown adipose tissue-like property in the white adipose tissue of fsp27 deficient mice. PLoS One 3: e2890, 2008.

139. Tokuyasu KT, Maher PA, Singer SJ. Distributions of vimentin and desmin in developing chick myotubes in vivo. I. Immunofluorescence study. J Cell Biol 98: 1961-1972, 1984.

140. Varela GM, Antwi DA, Dhir R, Yin X, Singhal NS, Graham MJ, Crooke RM, Ahima RS. Inhibition of ADRP prevents diet-induced insulin resistance. Am J Physiol Gastrointest Liver Physiol 295: G621G628, 2008.

141. Vaughan M, Berger JE, Steinberg D. Hormone-sensitive lipase and monoglyceride lipase activities in adipose tissue. J Biol Chem 239: 401-409, 1964.

142. Villena JA, Roy S, Sarkadi-Nagy E, Kim KH, Sul HS. Desnutrin, an adipocyte gene encoding a novel patatin domain-containing protein, is induced by fasting and glucocorticoids: ectopic expression of desnutrin increases triglyceride hydrolysis. J Biol Chem 279: 47066-47075, 2004.

143. Wang SP, Laurin N, Himms-Hagen J, Rudnicki MA, Levy E, Robert MF, Pan L, Oligny L, Mitchell GA. The adipose tissue phenotype of hormone-sensitive lipase deficiency in mice. Obes Res 9: 119-128, 2001.

144. Wang Y, Sullivan S, Trujillo M, Lee MJ, Schneider SH, Brolin RE, Kang YH, Werber Y, Greenberg AS, Fried SK. Perilipin expression in human adipose tissues: effects of severe obesity, gender, and depot. Obes Res 11: 930-936, 2003.

145. Watt MJ, Heigenhauser GJ, O’Neill M, Spriet LL. Hormone-sensitive lipase activity and fatty acyl-CoA content in human skeletal muscle during prolonged exercise. J Appl Physiol 95: 314-321, 2003.

146. Watt MJ, Holmes AG, Pinnamaneni SK, Garnham AP, Steinberg GR, Kemp BE, Febbraio MA. Regulation of HSL serine phosphorylation in skeletal muscle and adipose tissue. Am J Physiol Endocrinol Metab 290: E500-E508, 2006.

147. Watt MJ, Steinberg GR, Chan S, Garnham A, Kemp BE, Febbraio MA. Beta-adrenergic stimulation of skeletal muscle HSL can be overridden by AMPK signaling. FASEB $J$ 18: 1445-1446, 2004.

148. Watt MJ, van Denderen BJ, Castelli LA, Bruce CR, Hoy AJ, Kraegen EW, Macaulay L, Kemp BE. Adipose triglyceride lipase regulation of skeletal muscle lipid metabolism and insulin responsiveness. Mol Endocrinol 22: 1200-1212, 2008.

149. Wijkander J, Landstrom TR, Manganiello V, Belfrage P, Degerman E. Insulin-induced phosphorylation and activation of phosphodiesterase $3 \mathrm{~B}$ in rat adipocytes: possible role for protein kinase B but not mitogenactivated protein kinase or p70 S6 kinase. Endocrinology 139: 219-227, 1998.
150. Wolins NE, Brasaemle DL, Bickel PE. A proposed model of fat packaging by exchangeable lipid droplet proteins. FEBS Lett 580: 5484 5491, 2006.

151. Wolins NE, Quaynor BK, Skinner JR, Schoenfish MJ, Tzekov A, Bickel PE. S3-12, adipophilin, and TIP47 package lipid in adipocytes. J Biol Chem 280: 19146-19155, 2005.

152. Wolins NE, Quaynor BK, Skinner JR, Tzekov A, Croce MA, Gropler MC, Varma V, Yao-Borengasser A, Rasouli N, Kern PA, Finck BN, Bickel PE. OXPAT/PAT-1 is a PPAR-induced lipid droplet protein that promotes fatty acid utilization. Diabetes 55: 3418-3428, 2006.

153. Wolins NE, Rubin B, Brasaemle DL. TIP47 associates with lipid droplets. J Biol Chem 276: 5101-5108, 2001.

154. Wolins NE, Skinner JR, Schoenfish MJ, Tzekov A, Bensch KG, Bickel PE. Adipocyte protein S3-12 coats nascent lipid droplets. J Biol Chem 278: 37713-37721, 2003.

155. Wu C, Zhang Y, Sun Z, Li P. Molecular evolution of Cide family proteins: novel domain formation in early vertebrates and the subsequent divergence. BMC Evol Biol 8: 159, 2008.

156. Xu G, Sztalryd C, Londos C. Degradation of perilipin is mediated through ubiquitination-proteasome pathway. Biochim Biophys Acta 1761: 83-90, 2006

157. Xu G, Sztalryd C, Lu X, Tansey JT, Gan J, Dorward H, Kimmel AR, Londos C. Post-translational regulation of adipose differentiation-related protein by the ubiquitin/proteasome pathway. J Biol Chem 280: 4284142847, 2005

158. Yamaguchi T, Matsushita S, Motojima K, Hirose F, Osumi T. MLDP, a novel PAT family protein localized to lipid droplets and enriched in the heart, is regulated by peroxisome proliferator-activated receptor alpha. J Biol Chem 281: 14232-14240, 2006.

159. Yamaguchi T, Omatsu N, Matsushita S, Osumi T. CGI-58 interacts with perilipin and is localized to lipid droplets. Possible involvement of CGI-58 mislocalization in Chanarin-Dorfman syndrome. J Biol Chem 279: 30490-30497, 2004.

160. Yamaguchi T, Omatsu N, Morimoto E, Nakashima H, Ueno K, Tanaka T, Satouchi K, Hirose F, Osumi T. CGI-58 facilitates lipolysis on lipid droplets but is not involved in the vesiculation of lipid droplets caused by hormonal stimulation. J Lipid Res 48: 1078-1089, 2007.

161. Yamaguchi T, Omatsu N, Omukae A, Osumi T. Analysis of interaction partners for perilipin and ADRP on lipid droplets. Mol Cell Biochem 284: 167-173, 2006.

162. Zimmermann R, Strauss JG, Haemmerle G, Schoiswohl G, BirnerGruenberger R, Riederer M, Lass A, Neuberger G, Eisenhaber F, Hermetter A, Zechner R. Fat mobilization in adipose tissue is promoted by adipose triglyceride lipase. Science 306: 1383-1386, 2004. 